\title{
The Lydian nominal paradigm of $i$-mutation
}

\author{
David Sasseville* \\ Philipps-Universitaet Marburg \\ dvdsasseville@web.de
}

\begin{abstract}
This paper offers an analysis of the Lydian nominal paradigm of $i$-mutation. The main goal is to uncover the accentual type of this paradigm. This is achieved, first, by analyzing the phonological outcome of the endings and, second, by identifying the position of the accent within each given lexeme. In the end, a barytone character is posited for this paradigm. This observation has consequences regarding the original distribution of $i$-mutation in Anatolian and its chronological spread.
\end{abstract}

\section{Keywords}

Anatolian - Lydian - nominal morphology - accentuation - $i$-Mutation - Lydian poetic meter

\section{Introduction}

The following paper deals with the grammar of Lydian, a poorly attested language belonging to the Anatolian branch of the Indo-European family. Although most of the nominal endings of the Lydian language are known, an extensive and comprehensive classification of all nominal stem classes is lacking so far in the literature. Recent works on Lydian grammar such as Gérard's Phonétique et morphologie de la langue lydienne make mention of nominal

* The analysis presented in this paper has been made possible by the project eDiAna "Electronic Dictionary of the Anatolian small corpus Languages", which is financed by the DFG "Deutsche Forchungsgemeinschaft". I would also like to acknowledge the esteemed contribution of Xander Vertegaal and Stefan Norbruis, who read and commented on an earlier draft of this paper. Any remaining errors are my own responsibility.

(C) DAVID SASSEVILLE, 2017 | DOI: $10.1163 / 22125892-00501002$

This is an open access article distributed under the terms of the prevailing CC-BY-NC license at the time of publication. 
stems (Gérard 2005:79-91), but provide no synchronic paradigm of the various nominal stem classes. Hajnal (2004), on the other hand, attempts an analysis of nominal paradigms, but deals with three large nominal stem classes within a single article. A precise classification of these classes is relevant not only for the grammatical annotation of Lydian lexemes, but also for Anatolian historical grammar in general. Thus, the present paper provides a synchronic and diachronic analysis of one nominal stem class as well as its corresponding paradigm. The nominal stem class selected for this paper is the one with $i$ mutation, which is left out by Hajnal (2004) in his study on Lydian $a$-stems. An additional goal of this paper is to shed light on the chronology of the spread of the Luwic $i$-mutation to various nominal stems. ${ }^{1}$

Determining the position of the accent

Due to the pioneering work of Eichner (1986a, 1986b) on Lydian accentuation, we are now aware that this language more often than not provides precise information regarding the position of the accent within a word. For example, the Lydian vowels $\tilde{e}, \tilde{a}, e$ and $o$ always carry the accent, except in preverbverb combinations and compounds, where more than one of these vowels may appear, and thus one of them is accented or carries only a secondary accent. However, the metrical inscriptions scanned by Eichner (1986a:16-21) demonstrate that preverbs are regularly unaccented. The vowels $a, i$ and $u$ can be either accented or unaccented, but the occasional plene spelling in - $a a-$ and -ii- is a device used by the Lydians to indicate that the vowel is accented. On the other hand, vocalic liquids $(\lambda, r)$ and vocalic nasals $(\nu, n)$ are normally unaccented. Another means for determining the position of the accent was provided by Eichner (1986a), as he, in our opinion, has deciphered the Lydian poetic meter. ${ }^{2}$ By properly scanning a verse, the position of the accent in a given word is revealed. In this respect, Lydian has a great advantage over the other Anatolian languages.

1 I follow the new conventions of using $\langle\mathrm{p}\rangle$ instead of $\langle\mathrm{b}\rangle,\langle\mathrm{s}\rangle$ instead of $\langle\dot{s}\rangle$ and $\langle\check{s}\rangle$ instead of

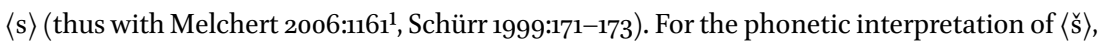
I simply follow the traditional view that it represents the palatal fricative [ç], for which see Gérard 2005:23, 60 with further literature.

2 For a summary regarding the steps of the decipherment and the contribution of Martin L. West see Gérard 2005:52-56. However, there are still diverging opinions regarding the Lydian meter and verse scansion; cf. Schürr 2003:115-125, Bachvarova 2004, Mercado 2007. 
TABLE 1 The Lydian paradigm of

the $\mathrm{i}$-mutated endings

\begin{tabular}{lll} 
Stems in $-(i)-$ & sg. & pl. \\
\hline nom. & $-i \check{s}$ & $-i \check{s}$ \\
acc. & $-\nu,-n$ & $-i s$ \\
nom./acc. n. & $-i d$ & $-a,-\varnothing$ \\
dat.(/gen.) & $-\lambda$ & $-a \nu$ \\
\hline
\end{tabular}

3

The paradigm of $i$-mutation

The paradigm of the $i$-mutated stems represents an innovation shared by Luwian, Lycian and Lydian (cf. Starke 1990:56-93, Zeilfelder 2001:215-228, Rieken 2005:49f.). The process of $i$-mutation consists on the one hand of replacing the thematic vowel *-o- with the vowel $-i$ - in the nominative and accusative, singular and plural of the common gender. Thus, this paradigm represents on the inflectional level a syncretism between the Proto-Indo-European $i$-stems and thematic $o$-stems. Furthermore, the morpheme $-i$ - is added to a stem-final consonant in the same cases, numbers and gender as for the thematic $o$-stems, e.g. $-n t-+-i-\rightarrow-n t(i)-$, thus causing another paradigmatic merger.

As shown by Eichner (1986b:212-217), a barytone nominal stem may show a different set of stem-finals than an oxytone one. This can be observed among $a$-stems, where the vowel - $a$ - in front of a nasal will show a different outcome depending on whether it is originally long or short, accented or unaccented, i.e. acc. sg. $-\tilde{e} \nu\left(<{ }^{*}-o-m\right),-\tilde{a} \nu\left(<{ }^{*}-\hat{a}-m\right)$ versus $-a v(<*-\grave{V}-m)$ (cf. Hajnal 2004). What is missing so far in the literature is the accentual pattern of the paradigm of $i$ mutation. In the next section, this paradigm will be presented and its endings will be phonologically evaluated. Afterwards, the lexical data constituting this paradigm will be examined and the position of the accent determined for each given lexeme.

\section{Inflectional endings and phonology}

The paradigm of $i$-mutation is given above. The lexical data constituting this paradigm are presented and analyzed from section 4.1 to 4.9 .

A striking feature of this paradigm is the consistent syncope found in the

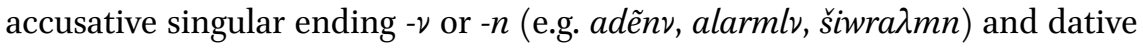


singular ending $-\lambda$ (e.g. niwisl $\lambda$, qaašl $\lambda$, sfardêt $\lambda$ ). This speaks a priori for a barytone paradigm. It has already been established that unaccented vowels in final syllables are syncopated in Lydian (Melchert 1994:373f.). However, only vowels that were originally short are expected to show syncope. The originally long ones are preserved (cf. Melchert 1994:379).

This syncope points towards the fact that the accusative and dative singular endings must have been short originally, i.e. $-\nu<{ }^{*}-\check{\iota}-n \leftarrow^{*}-\breve{o}-m$ and $-\lambda<{ }^{*}-\breve{a} \lambda$. The fate of the accusative singular ending demonstrates that the vowel $-i$ - of the mutation was short. This observation is in contradiction with the assumption that this vowel in Luwian is long, as advanced in Melchert 2003:188 and Rieken 2005:6 $7 .^{3}$ On the other hand, endings containing an original long vowel do not undergo syncope. For example, the dative/genitive plural ending of the paradigm under discussion is not ${ }^{* *}-\nu$, but $-a \nu<{ }^{*}-\bar{a} m<{ }^{*}$-o-om (e.g. fẽntašẽnav, sfardẽtav, ištaminlav). The absence of the vowel $-\tilde{e}-$ or $-\tilde{a}$ - before the nasal $-\nu$ brings support to the unaccented status of the dative/genitive plural ending.

Likewise, the nominative plural ending -iš (e.g. sfẽniš, šiwra入miš) surely equates to the Luwian nominative plural ending -inzi probably with compensatory lengthening, i.e. $-i \check{s}<{ }^{*}-{ }^{-} \bar{s} i<{ }^{*}-i n s+-i{ }^{4}$ The ending of the accusative

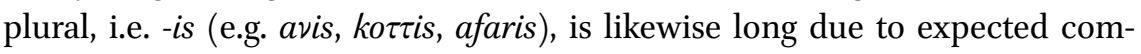
pensatory lengthening, i.e. ${ }^{*}-i s<{ }^{*}$-ins ${ }^{*}{ }^{*}$-o-ns and, therefore, does not show syncope. ${ }^{5}$ As opposed to the nominative plural ending -ǐs, which shows palatalization because of the additional morpheme ${ }^{*}-i$, the accusative plural does not show traces of it. This situation is the same as the one we have in Kizzuwatna Luwian, i.e. nom. pl. -inzi $\left(<{ }^{*}\right.$-insi), acc. pl. -inz $(a)\left(<{ }^{*}\right.$-ins). ${ }^{6}$ Moreover, this brings additional evidence that the nasal in Lydian was dropped before /s/ after the palatalization process took place (cf. Melchert 1994:382).

The neuter singular ending -id (e.g. wiswid, tesastid, manelid), like its nonmutated counterpart -ad, reflects an extension of the stem vowel with the

3 Rieken (Handout 2016) now shows that the morpheme - $i$ - of mutated stems in Cuneiform Luwian is not written with a plene spelling except after $/ \mathrm{u} /$, which is simply a graphic feature, and in adjectives in -i(ya)-(<*-iio- with $i$-mutation), which reflect a long $/ \mathrm{i}: /\left(<{ }^{*}\right.$-iiii-) .

4 Cf. Gérard 2005:80 f., Melchert 2009:113. The alternative scenario proposed by Gérard (2005:81), according to which it comes from ${ }^{*}-i$-es, does not take into account the common innovation of the paradigm of $i$-mutation shared by Luwian, Lycian and Lydian.

5 I consider words ending in -is to be accusative plural, which accounts for the lack of palatalization of the final -s, i.e. -is < *-ins (cf. Gérard 2005:81f.). The syntactic interpretation of avis

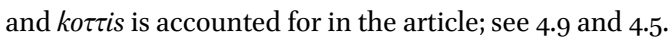

6 For the dialectal difference in the nominal endings between Kizzuwatna and Empire Luwian, see Yakubovich 2010:26-38. 
pronominal neuter ending - $d$ (Gérard 2005:80). This is an innovation vis-àvis e.g. Hitt. -an, Lyc. $-\tilde{e}\left(<\mathrm{PIE}{ }^{*}-\mathrm{om}\right)$, which can be dated to Pre-Lydian. No syncope occurs in this ending, although the vowel in the ending -id $(-\breve{-}-d \leftarrow-\breve{a} d$ $\left.<{ }^{*}-\check{ }-d\right)$ is certainly short. Therefore, one could posit that the ending - $V d$ was created after the Pre-Lydian syncope took place, thus replacing an expected * $-\nu / \mathrm{n} /$. Alternatively, if the analogical extension had already taken place, one could claim that the absence of syncope is due to the fact that Lydian will not tolerate certain consonant clusters, e.g. lid, not **-ld (cf. Melchert 1994:353, 374). An anonymous reviewer makes me aware that the second option is superior, if one assumes ciward comes from *iwarid. In this case, a final cluster - $r d$ would be tolerated in Lydian as opposed to e.g. ${ }^{* *}$-ld. The latter solution seems to us preferable, especially if one considers the similar reasons for the lack of syncope in the nominative singular ending -iš discussed below.

As opposed to Luwian and Lycian, the Lydian language has extended the $i$-mutation to some neuter endings. The extension appears to be restricted to adjectival neuter stems (see 4.2 and 4.4). The reason behind this might be that the adjectival neuter stems share a paradigm with their common gender counterpart, which motivates the extension process; the nominative/accusative neuter singular takes over the $i$-mutation by paradigmatic levelling. Nonmutated adjectival $a$-stems ( $\left.<{ }^{*}-o^{-}\right)$on the other hand will not show $i$-mutation in the neuter, just as it is the case in the common gender; cf. $a \lambda a$ - 'other'

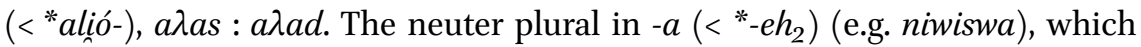
was originally long for thematic stems, is rarely attested with adjectives. The paucity of its attestations might be due to the fact that collectives or neuter plurals seem to be agreeing with adjectives in the neuter singular (e.g. LW 5.23) or with the endingless case marker (e.g. LW 54.1-2).

The nominative singular common gender ending $-i \check{s}<{ }^{*}-\breve{-}-s<{ }^{*}-\breve{o}-s$ (wissiš, qaašliš, maneliš), although short in origin, did not undergo syncope. The reason for this must be a prohibition on the word-final consonant sequences just like the more probable explanation of the neuter singular ending -id. A very small number of sequences - $C \check{s} \#$ reflecting nominative singulars can be found in

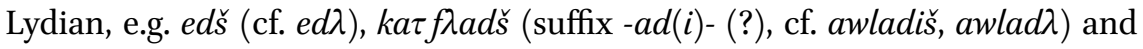
patnẽdš, all showing the sequence -dš. Because of the palatalization of the ending $-s$, these words must have a mutated stem, and one can conclude that the $-i$ - of the nominative singular ending can only be dropped following $-d$ -

Based on this observation, one could argue that the endings of the nominative and accusative plural -iš and -is follow the same restrictive rule as the one of the nominative singular. However, since the syllable was long originally and we do not expect their vowel to drop like in the dative plural - $a v$, it is better to retain the explanation with the length of the vowel (see above). If 
nominative plural forms in - diš were to be found beside singulars in - $d \check{s}$, it would vindicate our hypothesis. ${ }^{7}$

Based on these observations, one can affirm that short vowels in the endings of this paradigm underwent syncope in Pre-Lydian, which points towards a barytone paradigm. An investigation of lexemes belonging to this paradigm is necessary before drawing conclusions about the accentual type of the entire nominal class. The investigated lexemes will be divided according to their respective suffix and stem formation.

\subsection{Original i-stems}

There are nouns in - $c(i)$ - c. $\left(<{ }^{*}-d i\right.$ - with lenition $<{ }^{*}$-ti-), which go back to proterokinetic $i$-stems (Melchert 1997:34f.), e.g. taac $(i)$ - c. 'votive offering' attested as acc. sg. $\operatorname{tacv}$ (LW 43.3), tacn (LW 41.5), taacn (LW 50.3), dat. sg. taach (LW 45.5), and perhaps kolc(i)- '?' attested as nom. sg. kolciš (LW 15.2). Because of the plene spelling in the first example and the vowel -o- in the second as well as the syncope in the accusative and dative singular endings, these lexemes must be considered barytone.

\subsection{Adjectivization in -(i)-}

The adjective wiss(i)-/wisw(i)- 'good, pious' represents an adjectivization of the substantive * $h_{1}$ ósu-l$/ h_{1}$ uésu- 'goods' by addition of a morpheme subject to $i$ mutation. Since $u$-stems do not take $i$-mutation in neither Luwian nor Lydian, the reconstruction of an additional morpheme is necessary. Moreover, the raising of a short $-e$ - to $-i$-in the sequence $w \_s$ (or any coronal) in Lydian is made difficult by the counterexample wesfa-. Therefore, I assume an adjectivization in * ${ }^{*} o$ - with a vrddhi-ablaut of the root, i.e. * $h_{1} u e \bar{s} s u-o^{-}$-, and retraction of the accent followed by $i$-mutation, i.e. * uisu-o/i-. ${ }^{8}$ Its antonym is built by means of adding the prefix ni-, i.e. niwiss $(i)$ - 'bad, unpious'. They are attested as nom. sg. c. wissiš (LW 6.5; 8.11; 10.23; 11.12), dat. sg. niwisl (LW 24.10), nom./acc. sg. n. wiswid (LW 22.3, 6), nom./acc. pl. n. niwiswa (LW 44a.17), adv. niwiscv (LW 6.5; 7.6; 8.11; 10.24; 23.3). ${ }^{9}$ There are two indications of its barytone character. The first one is drawn from a metrical inscription, where the accent occurs on the first syllable:

7 The form awladiš (LW 80.14), which could be nominative singular or plural, is found in a fragmentary passage, and therefore its number cannot be verified independently.

8 I owe the morphological explanation of Lyd. wiss $(i)-/ w i s w(i)$ - to an anonymous reviewer. For the retraction of the accent in morphologically unanalyzable forms, see Yates 2015 .

9 Pace Schürr (2006:1574f.), the ending $-c v$ is an adverbial marker, which is irrelevant for the discussion on the etymology of the stem wiss $(i)-/ w i s w(i)$-. For the alternation of -ss/-sw-, perhaps one should compare Hieroglyphic Luwian abl./instr. (BONUS $\left.{ }_{2}\right) w a / i-s a ̀-t i$ vs. 


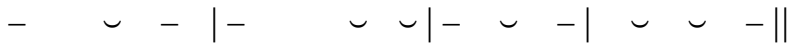

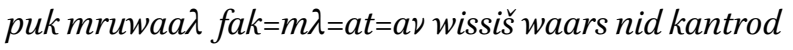

LW 11.12

The third foot must be scanned this way, since an anaclasis of the type $\mid \smile-$ - | would be unparalleled in the Lydian poetic meter (cf. Eichner 1986a:18f.). The second one is the attestation in the dative singular niwisl $\lambda\left(<{ }^{*}\right.$ niwiss $\lambda$ + assimilation), which shows syncope of the vowel in the ending. This syncope excludes the possibility of an oxytone type and, since the accent is not expected to be on the prefix, it must be on the root, i.e. * niwiswa $>$ > niwiss $\lambda$ > niwisl $\lambda .^{10}$

\subsection{The suffix -ẽn(i)-}

According to Hajnal (2004:189), the suffix -ẽn(i)- c., which he sees in sfẽn $(i)$ - c. 'parent, kin', goes back to a thematic stem in *-no-, i.e. -ẽn $(i)-<{ }^{*}$-énno/i- with Čop's law and $i$-mutation $<{ }^{*}-e_{-}-n o-$. This suffix surely corresponds to the Luwian suffix -anna/i- in e.g. niwaranna/i- c. 'child' (Starke 1990:452), arawanna/i- c. 'free person' (Rieken \& Sasseville 2014:305).11 The Lydian suffix always carries accent on the first syllable and, therefore, each derivative in -ẽn $(i)$ - is barytone, e.g. sfẽn(i)- c. 'parent, kin' attested as nom. pl. sfêniš (LW 24.16, 80.5), dat. pl. sfẽnav (LW 42.5), fẽntašẽn(i)- c. (a group of people), attested as dat. pl. fẽntašẽnav (LW 12.10, 22.4), irẽn(i)- c. '?' attested as acc. sg. irẽnv (LW 15.6),

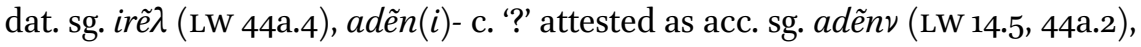

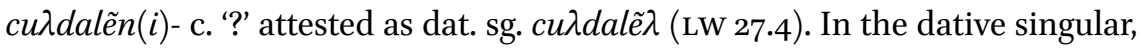
the stem-final *-en $\lambda$ is reduced to $-\tilde{e} \lambda$ (cf. Kloekhorst 2012:1665). The barytone character of these examples is confirmed not only by the accented vowel $-\tilde{e}$ - of the suffix, but also by the syncope in the accusative and dative ending. Moreover, the lack of accentual indication in the dative plural -av (e.g. sfẽnav, fẽntašẽnav) provides further evidence in support of the conclusion that derivatives in -ẽn $(i)$ - are barytone.

nom./acc. sg. n. $w a / i-s u$ (Rieken 2010:658f.), but a simple assimilation of the cluster -sw- > -ss- in the nominative singular, which is motivated by the following $-s$ in the ending, would be sufficient.

10 As pointed out in section 2, in Eichner's metrical system preverbs or prefixes do not carry the accent.

11 Cf. Starke 1990:62 et passim. A thorough semantic, derivational and etymological analysis of this suffix in Anatolian is long overdue. 


\subsection{The suffix $-\mathrm{l}(\mathrm{i})-$}

The adjectival suffix $-l(i)-\left(<{ }^{*}-(e ́)-l o\right.$ - with $i$-mutation; see Starke 1990:85), which has been grammaticalized as an adjectival genitive, is also found in substantivized and lexicalized derivatives. This suffix corresponds to Luwian -alla/i-, Lyc. -ele/i- and Hitt. -ēl- $\left(<{ }^{*}-e-l o-\right) .{ }^{12}$ Derivatives in ${ }^{*}$-é-lo- were originally barytone and they are mutated in Lydian. We note here that the connecting vowel *-é- before the suffix *-lo- has lost its accented status in Lydian and has been dropped. Consequently, the suffix was reanalyzed as $-l(i)-.^{13}$ Due to its productivity, most Lydian formations in $-l(i)$ - are surely late and one should not posit a change in the accent to have occurred within each available lexeme. The first example treated here is the adjective $\operatorname{arlill}(i)$ - 'one's own' attested as

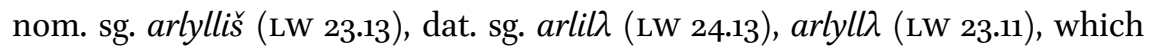
cannot be oxytone because of the syncope in the dative singular ending. Since the vacillation $-i-/-y$-in the second syllable reflects the lack of accent (Melchert 1994:342 f.), the lexeme $\operatorname{arlill}(i)$ - must be accented on the first syllable (Melchert 1999b:2432 245). The double -ll- must reflect an assimilation, perhaps from a cluster -dl-, i.e. ${ }^{*} \operatorname{arl}-$-id-l( $(i)$ - $>\operatorname{arlill}(i)-.{ }^{14}$

The next examples represent substantivized adjectives in -l(i)-, e.g. šerl(i)c. 'high authority' (< ${ }^{*}$ sér-lo- $)^{15}$ attested as nom. sg. šerliš (LW 24.4, 24.16), ištaminl(i)- c. 'family (?)' attested as nom. sg. ištaminliš (LW 13.2) and as gen. pl. ištaminlav (LW 13.7). The last lexeme is attested in a metrical inscription and the accent falls on the penultimate syllable:

$$
-\smile \quad-|\smile-\cup| \cup--|\smile \sim-| \mid
$$

$a m u=k n \tilde{a} \tilde{s} i=k$ ẽmiš ištaminliš wstaas

LW 13.2

$$
\begin{aligned}
& -\quad \cup|\cup-\cup| \cup \backsim-|\cup \smile-| \mid \\
& \text { fak }=\tau=\text { in dawicil ištaminlav qiraad } \\
& \text { LW } 13.7
\end{aligned}
$$

12 For the origin of the Hittite suffix, see Rieken 2008.

13 Accent shift followed by syncope of the previously accented vowel is very common in Lydian, especially if one takes the comparative data of Luwian and Lycian into consideration, e.g. Lyd. - $\tau a-$ c. (Schürr 2006:1577) with Luw. -azza- c. and Lyc. -aza- c. (< ${ }^{*}$-é-tieh ${ }_{2}$, the position of the accent is given away by Hitt. -ezziya- <*-é-tio-, cf. Kloekhorst 2008:264f.), Lyd. -la- c. (Sasseville 2014/2015:117 f.) with Luw. -alla- c. and Lyc. -ala- (<*-é-leh $)$, cf. also qaša $a$ - and its genitival adjective analyzed further below.

14 For an etymological proposal of Lyd. $\operatorname{arlill}(i)$-, see Melchert 1999b.

15 This example is reconstructed without a connecting vowel *-é- because of Luwian $/ \operatorname{sarl}(\mathrm{a}) \mathrm{i}^{-(\mathrm{di})} /$, where it is lacking. 
Because of the presence of the vowel -o- in the first syllable, the following derivatives are clearly barytone, e.g. porl $(i)$ - c. 'year' attested as nom. sg.

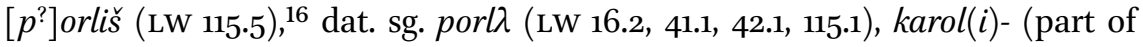
a grave) attested as dat. sg. karol ( $\mathrm{LW} 4 \mathrm{4} \cdot 3$ ). ${ }^{17}$ The following example shows plene spelling in the first syllable, which indicates a barytone accentuation, i.e. qaašl( $i$ )- c. '?' attested as nom. sg. qaašliš (LW 12.5) and dat. sg. qaašl (LW 12.2).

The adjectival suffix $-l(i)$ - in its genitival use has a nominative plural in -l like the collective instead of the expected *-liš (Heubeck 1983:64f., Schürr 1997:209, Gérard 2005:84f.). This zero-ending is another piece of evidence in favor of the barytone type for formations in $-l(i)$-. The following examples represent cases of genitival adjectives derived from proper nouns, e.g. karo$(\mathrm{PN}) \rightarrow \operatorname{karol}(i)$ - attested as nom./acc. sg. n. karolid (LW 2.4), dat. sg. karol $\lambda$ (LW 2.8, 10.2), dat./gen. pl. karola(v) (LW 2.9), katowa- (PN) $\rightarrow$ katowal ( $i)$ - attested as nom. sg. c. katowalis (LW 10.1, 11.7), nom./acc. sg. n. katowali(d) (LW 8.5), dat.

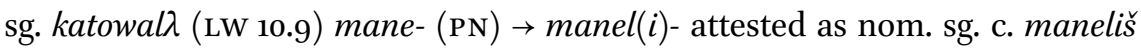
(LW 4a.1, 4b.1), nom./acc. sg. n. manelid (LW 1.4), nom./acc. coll. manel (LW 55, 56, 73), $\operatorname{artimu-~} \rightarrow \operatorname{artimul}(i)$ - attested as nom. sg. c. artimuliš (LW 25.5), dat. sg.

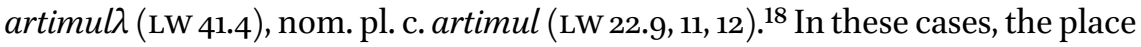
of accent in the genitival adjective does not differ from the base noun. This is supported on the one hand by the retention of the accented vowel $o$ for karol $(i)$ and katowal $(i)$ - or $e$ for manel $(i)$-and, on the other hand, by the syncope in the dative singular and by the zero ending of the nominative plural and collective.

The amount of data for genitival adjectives built from appellatives is meagre. Nevertheless, one can observe that when the genitival adjective in $-l(i)$ - is derived from an oxytone $a$-stem, the accent shifts to the beginning of the word and then the previously accented vowel is immediately syncopated, e.g.

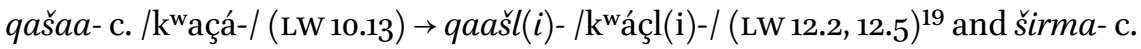

16 For the publication of the inscription LW 115, see Gusmani \& Akkan 2004. For the numbering of the latest Lydian inscriptions, see Payne \& Wintjes 2016: $77^{80}$.

17 Pace Schürr (1997:202 $\left.{ }^{3}\right)$ and Gérard (2005:81f.), karolas cannot be the accusative plural of the mutated stem karol( $i$ )- (part of a grave), because the accusative plural ending should be mutated. Therefore, it must be taken with Melchert (1991:132f.) as $\operatorname{karola}(\nu)=s$, the possessive adjective of the personal name karo-.

18 Based on one attestation in a metrical inscription, we can posit that the divine name Artemis in Lydian is accented on the first syllable, i.e. /ártimu-/ (Eichner 1986a:18).

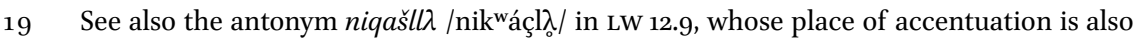
shown by the poetic meter. The word niqaašlad (LW 14.6; 80.6) must be a denominative verb in the 3 rd sg. pres. derived from niqašl $(i)$-, since the neuter singular ending of the adjective in $-l(i)$ - would be *niqašlid. 
/çirmá- $/ \rightarrow$ šrml $(i)-/$ çŕml(i)-/. ${ }^{20}$ This also means that the vocalic resonant in šrml $(i)$ - is secondarily accented by analogy, in which case the resonant does not vocalize to $-i-/-y$-, pace Eichner 1986a:21 ${ }^{26}$ and Melchert 1994:350. ${ }^{21}$ Further evidence for its accented status can be adduced from the rest of the data on stems in $-l(i)-$, which point towards a barytone type.

The lexeme alarm- c. '(one)self', which is barytone, has one attestation of a genitival adjective:

$$
\begin{aligned}
& \smile \smile-|-\smile \cup|-\cup-|\cup--| \mid \\
& \text { caqrlãv ak=um adẽnv alarmlv étolt }{ }^{22} \\
& \text { LW } 14.5
\end{aligned}
$$

The accent is on the second syllable and the ending shows syncope, i.e. /alármlı̊/, thus the genitival adjective is barytone as well. Pace Melchert (2006: $1163^{9}$ ), Lyd. alarm- c. '(one)self' is synchronically a consonantal stem and not a barytone $a$-stem. No restitution of the vowel - $a$ - occurs in the suffix. The case of alarmas (LW 13.1) instead of regular alarms, which has been wrongly used as an argument for a general restitution of the vowel $-a$-in barytone $a$-stems, serves a metrical purpose (cf. Eichner 1985a:17). The suffix - $m$ - c. probably goes back to the neuter suffix *-mn-, which was remade into a common gender consonantal stem. This etymological approach is supported by Lyd. êtam-c., from which the denominative verb in *-ie/o-preserved traces of the original shape of the suffix, i.e. fẽtamv-i- (contra Gusmani 1964:126, 172).

In sum, the examples shown above suggest not only through the presence of the vowel $\tilde{e}, \tilde{a}, o, e$ or $-a a$ - in a syllable other than the ultimate, but also through the syncope in the accusative and dative ending and through the lack of accentual indication, i.e. - $\tilde{e}$ - or - $\tilde{a}$-, in the dative plural - $a v$, that derivatives in $-l(i)$ - are barytone.

20 Further evidence for the oxytone property of širma- (< ${ }^{*}$ srméh ${ }_{2}$, cf. Lyc. hrmma- c.) is the vacillation $-i-/-y$ - in the first syllable, cf. šyrmas (LW 23.1). The unaccented original vocalic *-r- developed to *-ir-l-yr- (cf. Melchert 1994:363), e.g. pira- c. 'house' (< ${ }^{*} p r(n)$-ó-), contra Melchert 1994:367. For the spread of the root vowel quality of the weak stems to the strong stems in the southwest Anatolian languages, cf. CLuw. zārt- n. ( $\left.{ }^{*} \hat{k} \bar{e} r-{ }^{*}{ }^{*} \hat{k} r d-\right)$.

21 For a possible parallel for a secondarily accented resonant, see $\operatorname{srfast}(i)$ - in section 4.7.

22 No letter is missing from the space (pace Gusmani 1964:256). Traces of the initial $a$ - in alarmlv can be seen on the other side of the space occupied by the bas-relief (see Buckler 1924:30). This is also supported by the meter. 


\subsection{The suffix $-\check{\mathrm{s}}(\mathrm{i})-$}

The suffix $-\check{s}(i)-\left(<{ }^{*}-a \check{s}(i)-<{ }^{*}\right.$-osso- with $i$-mutation < ${ }^{*}$-osio-; see Melchert 2012:282-284) is related to Luw. /-assa/i-/ and Lyc. A -a/ehe/i- (Carruba 1959:187, Melchert 1994:337). Most of the derivatives in $-\check{s}(i)$ - are adjectives, while some are clearly substantivized. This suffix is found in $m \lambda w \tilde{e} \check{s}(i)$ - '?' attested as nom. sg. c. $m \lambda w \tilde{e} \tilde{s} i s ̌$ (LW 12.3), ${ }^{23}$ which is a derivative of * $m \lambda w \tilde{e} n(i)$ - (also found as the derivational base of $m \lambda$ wẽndav). The vowel - $\tilde{e}$ - speaks for a barytone type. There is another potential case, i.e. kopš(i)- '?', attested as nom. sg. c. kopšiš (LW 115.5), which is clearly barytone based on the letter - $o$ - in the initial syllable. It is probably derived from an unattested noun *kop $(V)$-. The last lexeme, i.e. prafrš $(i)$ - c. (title) attested as nom. sg. prafršiš (LW 23.7), dat. sg. prafrl入 (LW 23.7) and nom. pl.(?) [ pra]wršiš (LW 99), is derived from the substantive attested as prafrav (LW 47.2), which is barytone as well. Although the vowel - $a$ - in the initial syllable does not furnish any indication for or against being accented, the syncope in the dative singular ending prafrl $\lambda$ speaks for a barytone type.

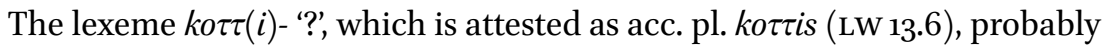
contains the suffix $-\check{s}(i)$ - as well. ${ }^{24}$ Since the sequence $-\tau \tau$ - is normally the

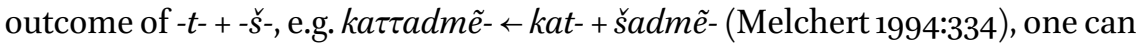
reconstruct a virtual Lydian pre-form *kuuatass $(i)$ - and postulate the following development: Pre-Lydian *kuúátass $(i)$ - > *kótaš $(i)->$ *kótš $(i)->k o \tau \tau(i)$-. In sum, Lydian derivatives in $-\check{s}(i)$ - are barytone.

\subsection{The suffix $-\mathrm{m}(\mathrm{i})$ -}

The Lydian suffix $-m(i)$ - (Carruba 1959:18 $)$ can be compared etymologically with the Luwian suffix $-m a / i-\left(<{ }^{*}-m o\right.$ - with $i$-mutation $)$ or with the Luwian participial suffix $-m m a / i$ - (or *-mn-o- with $i$-mutation). The thematic vowel ${ }^{*}-o$ - (i.e. $\left.-a / i-\right)$ in these suffixes is unaccented, which is supported by the lack of plene writing in Cuneiform Luwian (cf. Melchert 2014:206-209). One of

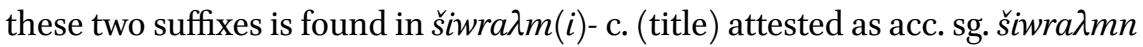
(LW 2.10), nom. pl. šiwra

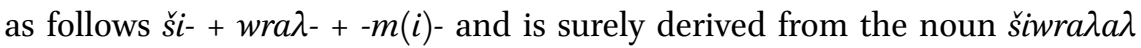
(LW 14.19). This denominal derivation speaks for an association with the Luwian suffix -ma/i- (<*-mo-) (Melchert 2014:208f.). Since the accent is not expected to be on the prefix ši-and since the accusative ending in šiwraגmn shows syncope, the accent must be on the remaining syllable, i.e. /çivrá $\lambda$ m(i)-/.

23 The adjective $m \lambda$ wẽ $̌$ iš must agree with šawkarplos (title) in LW 12.3.

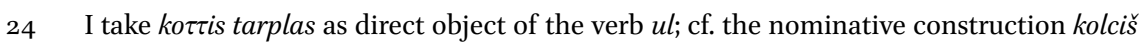
tarplas fẽnanil (LW 15.2) with the ending -iš in kolciš. 
The following example is asẽm( $i$ )- '?', attested as a nom. sg. c. asẽmiš (LW13.3), dat. sg. asẽm $\lambda$ (LW 13.9), where the vowel -ẽ- and the syncope in the ending shows that the lexeme is barytone. The vowel - $\tilde{e}$ - also indicates that the syllable was originally short and closed (Melchert 1994:348), and thus the identification with the participial suffix *-mno- with $i$-mutation is preferable, i.e. asẽm $(i)$ < "as-é-mn-o-. The last example, i.e. trišm(i)- '?', attested as acc. sg. c. trišmv (LW 44a.2), shows syncope in the ending $-\nu$, which speaks for a barytone type. In sum, derivatives in $-m(i)$ - are barytone.

\subsection{The suffix -ast(i)-}

There are two examples in Lydian of an adjectival suffix -ast $(i)$-, which goes back to *-os-to- (Melchert 1999a:365 f.). The first is tesast( $i$ )- 'right', attested as nom./acc. sg. n. tesastid (LW 5.2), and the second is srfast( $i$ )- 'left', attested as nom./acc. sg. n. srfastid (LW 5.3). The accentual type of the first example is clearly barytone based on the preserved vowel $-e-(<*$ é). The second example, on the other hand, is ambiguous. The accent could be on the vowel $-a-$, or on the vocalic $-r$ - in the root srf-. Even though vocalic resonants are generally unaccented, it could have received accent secondarily by analogy to other formations in -ast (i)- such as tes-ast $(i)$-. Because of the paucity of evidence, this last assumption must be considered tentative.

\subsection{The suffix -ẽt(i)-}

The suffix -êt $(i)-\left(<{ }^{*}\right.$-Vnt- with $i$-mutation) goes back to a consonantal stem. There is the lexeme sfardẽt $(i)$ - 'Sardian' attested as nom. sg. c. sfardêti( $\tilde{s})$ (LW 22.13), dat. sg. c. sfardẽt (LW 22.2), dat. pl. c. sfardẽtav (LW 22.8), sfardẽta(v) (LW 22.4). The substantivized nominative plural common gender form sfardẽn $\tau$ (LW 22.1 $)^{25}$ is strange, as one would expect sfardẽtiš. Perhaps, it is an endingless collective (cf. dẽt- below) followed by the emphatic particle $=s$, i.e. sfardẽt $+=s$ $\rightarrow$ sfardẽn $\tau{ }^{26}$ The position of the accent is indicated by the vowel -é- and, thus, this lexeme is barytone.

25 The word miimnas at the end of the line is interpreted here as accusative plural dependent on the postposition wicv; cf. Yakubovich forthcoming.

26 Another possibility is to assume syncope of the plural ending -iš, which is not expected to occur if the vowel is originally long. However, non-mutated consonantal stems seem to have a nominative plural ending -š, which probably goes back to a short vowel, *-ěs, e.g. ciwš 'the gods' (< * diu-es < PIE *dieu-es) (LW 44a.17). The hypothesis that this ending was beginning to extend to the paradigm of $i$-mutation is possible, but unprovable due to the lack of independent confirmation. 
The lexeme $\operatorname{det}(i)$ - 'movable goods' contains the same etymological suffix,

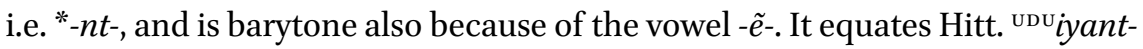
c. 'sheep' and goes back to a participial form * $h_{1} i-$ ónt- of the verb ${ }^{*} h_{1} e i_{n}-$ 'to go' (Gusmani 1964:99), which was substantivized already in Proto-Anatolian. It is attested as nom. coll. c. dẽt (LW 24.22), acc. sg. c. dẽtn (LW 24.20), nom./acc. coll. n. dẽt (LW 46.1) and there are probably more attestations, although it is questionable whether every word dêt attested in the Lydian corpus belongs to this lexeme. A nominative singular common gender form, where the $i$ mutation would be seen, is not yet attested. The endingless collective form cannot go back to the thematic collectives ${ }^{*}-e h_{2}$, which is preserved as $-a$, but must go back to the consonantal one ${ }^{*}-h_{2}$, i.e. ${ }^{*} h_{1}$ i-ónt- $h_{2}$ (Melchert apud Gérard 2005:113).

\subsection{Miscellaneous}

The following lexeme is hard to classify. The substantive $a v(i)$ - c. is attested as acc. pl. avis $^{27}$ (LW 11.3) in a metrical inscription:



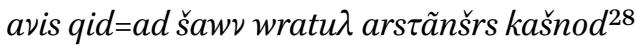

LW 11.3

Pace Eichner (1986a:18), the initial vowel in avis is surely accented. Scanning the foot as $|-\smile-|$ also makes the entire poem more homogeneous with respect to the first foot of each verse (cf. LW 11.1, 2, 5, 6, 9, 10, 11, 12). Besides, to scan the foot as $|---|$ is not an option; cf. section 4.2. The accented status of the vowel - $a-$ placed before a nasal without the expected outcome - $\tilde{e}$ - or - $\tilde{a}$ - is rare, but not unparalleled, e.g. tamv 'I built' / támñ/ (Eichner 1986a:11). These anomalies have not yet been explained satisfactorily, although one should notice here that both examples concern the root vowel. From a historical perspective, it is difficult to decide whether the substantive $a v(i)$-reflects a primary $i$-stem or a primary thematic $o$-stem, i.e. ${ }^{*}(H) V n$ - $i$ - or ${ }^{*}(H) V n$-o-, since both are well-established word formations. In any case, the preform must have been barytone.

27 I interpret iškos avis as the direct object of kazared and not as the subject. The subject of

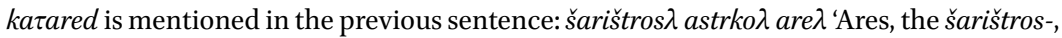
the astrko-'.

28 The unaccented status of šawv supports the hypothesis that it is a pre-/postposition (Boroday \& Yakubovich forthcoming). 
In spite of the small number of examples available for each type of nominal formation, the fact that all of them are uniform with regard to the accentual type allows us to conclude that the paradigm of $i$-mutation in Lydian is barytone. Regarding the etymological comparison of selected suffixes with Luwian and Lycian, an original barytone type for some of them, e.g. * ${ }^{*} e-n o-,{ }^{*}-(e ́-) l o-,{ }^{*}-m o-$ , * $-m n-o-$, has already been suggested. In the instance of the others, e.g. * ${ }^{*}$ osio-, *-os-to-, although further research is needed, a barytone character is very likely.

On the other hand, the original thematic $o$-stems that were accented on the suffix survive in Lydian as a separate class (Hajnal 2004:189-192) and show no $i$-mutation, e.g. dat./gen. pl. a $a \tilde{e} v$ 'other' < *ali-ó-om, acc. sg. tawsẽv 'powerful' < ${ }^{*} t e u H$-s-ó-m. If Lydian was consistent in this pattern, i.e. all oxytone $o$-stems escaped $i$-mutation, then it is expected that all barytone stems in ${ }^{*}-o$ - were affected by $i$-mutation. That would mean that barytone $o$-stems were the first ones to undergo $i$-mutation in the prehistory of Luwian, Lycian and Lydian. ${ }^{29}$ While Luwian and Lycian went on to eliminate the oxytone $o$-stems, Lydian preserved them intact. ${ }^{30}$

This observation calls into question the origin of the Lydian barytone $a$ stems, which never show syncope of the stem vowel - $a$-, e.g. wãna- c. 'grave' (cf. footnote 10). On phonological grounds, the stem vowel must have been originally long, in order to fully resist syncope. Therefore, an origin in * ${ }^{*} e h_{2}$ should be posited for the Lydian barytone $a$-stems, i.e. wãna- c. < "uónā- < "uón$e h_{2}$ (cf. HLuw. /wanid-/ n. 'stele' < "uón-id-). ${ }^{31}$ However, a full analysis of this nominal stem class cannot be presented here. Therefore, this conclusion must be regarded as provisional.

\section{6}

\section{Summary}

In this paper, the Lydian nominal paradigm of $i$-mutation has been extensively researched. After its endings were phonologically analysed, a barytone character for the paradigm was proposed. In order to verify this hypothesis, sub-

29 No chronology for consonantal stems can be established here, but it must await further research.

30 It should be noted that the exact fate of oxytone $o$-stems in Luwian and Lycian needs further research.

31 Since an accented $e$-grade of the root would have caused Čop's law to operate, I reconstruct an $o$-grade. 
stantives and adjectives belonging to this paradigm were classified according to their respective stem formation and, then, their accentuation type was identified. All verifiable lexemes turned out to be barytone, which was confirmed either by indication of an accented vowel in the penultimate or antepenultimate syllable, or by determining the position of the accent by scanning the metrical verse. In sum, the Lydian nominal paradigm of $i$-mutation is barytone. This paper will hopefully contribute to the ongoing research on the phenomenon of $i$-mutation in Anatolian, in which Lydian has so far received little attention.

\section{References}

Bachvarova, Mary R. (2004): Topics in Lydian verse. Accentuation and syllabification. Journal of Indo-European Studies 32. 227-247.

Boroday, Sergey \& Yakubovich, Ilya (forthcoming): Hittite local adverbs in comparative perspective.

Buckler, William H. (1924): Lydian Inscriptions, Part II. A collection of the texts in Lydian script found at Sardis and elsewhere. Sardis: Publications of the American Society for the Excavation of Sardis. Leiden: Brill.

Carruba, Onofrio (1959): Studi sul nome, sui preverbi e sulle particelle in lidio. Quaderni dell'Instituto di Glottologia dell'Università di Bologna4. 13-43.

Eichner, Heiner (1986a): Die Akzentuation des Lydischen. Die Sprache 32. 7-21.

Eichner, Heiner (1986b): Neue Wege im Lydischen I:Vokalnasalität vor Nasalkonsonanten. Zeitschrift für Historische Sprachforschung 99. 203-219.

Gérard, Raphaël (2005): Phonétique et morphologie de la langue lydienne. Bibliothèque des Cahiers de l' Institut de Linguistique de Louvain, 114. Louvain-la-Neuve: Peeters.

Gusmani, Roberto (1964): Lydisches Wörterbuch. Mitgrammatischer Skizze und Inschriftensammlung. Heidelberg: Winter.

Gusmani, Roberto / Akkan, Yilmaz (2004): Bericht über einen lydischen Neufund aus dem Kaystrostal. Kadmos 43. 139-150.

Hajnal, Ivo (2004): Die lydischen $a$-Stämme. In: Hyllested, Adam / Jørgensen, Anders R. / Larsson, Jenny H. / Olander, Thomas (ed.):Per Aspera Ad Asteriscos. Studia Indogermanica in honorem Jens Elmegard Rasmussen sexagenarii Indibus Martiis anno $M M I V$. Innsbrucker Beiträge zur Sprachwissenschaft 112. Innsbruck: Institut für Sprachen und Literaturen. 187-205.

Heubeck, Alfred (1983): Lydische Marginalien. Kadmos 22. 61-68.

Kloekhorst, Alwin (2008): Etymological Dictionary of the Hittite Inherited Lexicon. Leiden Indo-European Etymological Dictionary Series 5. Leiden / Boston: Brill.

Kloekhorst, Alwin (2012): The origin of the Lydian dat.sg. ending - $\lambda$. Kadmos 51. 165-173. 
Melchert, H. Craig (1991): The Lydian emphasizing and reflexive particle -ś/-is. Kadmos 30. 131-142.

Melchert, H. Craig (1994): Anatolian Historical Phonology. Leiden Studies in IndoEuropean, 3. Amsterdam / Atlanta: Rodopi.

Melchert, H. Craig (1997): PIE dental stops in Lydian. In: Adams, Douglas Q. (ed.): Festschrift for Eric P. Hamp. Vol. 2. Journal of Indo-European Studies. Monograph Series, 25. Washington, D.C.: Institute for the Study of Man. 232-247.

Melchert, H. Craig (1999a): Two problems of Anatolian nominal derivation. In: Eichner, Heiner / Luschützky, Hans C. (ed.): Compositiones Indogermanicae in memoriam Jochem Schindler. Praha: Enigma. 365-375.

Melchert, H. Craig (1999b): “(Zu)eignung” in Anatolian and Indo-European. In: Anreiter, Peter / Jerem, Erzsébet (ed.): Celtica et Indogermanica. Festschrift für Wolfgang Meid zum 7o. Geburtstag. Budapest: Archaeolingus. 243-247.

Melchert, H. Craig (2003): Language. In: Melchert, H. Craig (ed.): The Luwians. Handbook of Oriental Studies. Section One: The Near and Middle East, 68. Leiden / Boston: Brill. 170-210.

Melchert, H. Craig (2006): Medio-passive forms in Lydian? In: Bombi, Raffaella / Cifoletti, Guido / Fusco, Fabiana / Innocente, Lucia / Orioles, Vincenzo (ed.): Studi linguistici in onore di Roberto Gusmani II. Alessandria: Ed. dell'Orso. 1161-1166.

Melchert, H. Craig (2009[2010]): The animate nominative plural in Luvian and Lycian. In: Nedoma, Robert / Stifter, David (ed.): ${ }^{*} h_{2} n r$. Festschrift für Heiner Eichner (= Sprache 48). Wiesbaden: Harrassowitz. 112-117.

Melchert, H. Craig (2012): Genitive case and possessive adjective in Anatolian. In: Orioles, Vincenzo (ed.): Per Roberto Gusmani: studi in ricordo. Linguistica Storica e Teorica 1. Udine: Forum. 273-286.

Melchert, H. Craig (2014): Anatolian nominal stems in *-(C)o-. In: Oettinger, Norbert / Steer, Thomas (ed.): Das Nomen im Indogermanischen. Morphologie, Substantiv versus Adjektiv, Kollektivum. Akten der Arbeitstagung der Indogermanischen Gesellschaft vom 14. bis 16. September 2011 in Erlangen. Wiesbaden: Reichert. 205-214.

Mercado, Angelo O. (2007): A Lydian poem (Gusmani 11) re-examined. In: Jones-Bley, Karlene / Huld, Martin E. / Della Volpe, Angela / Dexter, Miriam Robbins (ed.): Proceedings of the 18th Annual UCLA Indo-European Conference. Los Angeles, November 3-4, 20o6. Journal of Indo-European Monograph Series 53. Washington, D.C.: Institute for the Study of Man. 143-159.

Payne, Annick \& Wintjes, Jorit (2016): Lords of Asia Minor. An Introduction to the Lydians. Wiesbaden: Harrassowitz.

Rieken, Elisabeth (2005): Neues zum Ursprung der anatolischen $i$-Mutation. Historische Sprachforschung 118. 48-74.

Rieken, Elisabeth (2008): The origin of the -l genitive and the history of the stems in -iland -ūl-in Hittite. In: Jones-Bley, Karlene / Huld, Martin E. / Dexter, Miram Robbins 
(ed.): Proceedings of the 19th Annual UCLA Indo-European Conference. Los Angeles, November 3-4, 2007. Journal of Indo-European Monograph Series 54. Washington, D.C.: Institute for the Study of Man. 239-256.

Rieken, Elisabeth (2010): Das Zeichen $\langle s a ̀\rangle$ im Hieroglyphen-Luwischen. In: Süel, Aygül (ed.): Acts of the VIIth International Congress of Hittitology, Çorum, August 25-31, 2008. Ankara. 651-660.

Rieken, Elisabeth (2016): Word-internal plene spelling in Kizzuwatna Luwian: With a focus on $\langle i\rangle$ and $\langle u\rangle$ vs. $\langle u$. Handout. 35th East-Coast Indo-European Conference Athens, GA, June 2016.

Rieken, Elisabeth \& Sasseville, David (2014): Social status as a semantic category of Anatolian: The case of PIE *-uo-. In: Melchert, H. Craig / Cifoletti, Guido / Fusco, Fabiana / Innocente, Lucia / Orioles, Vincenzo (ed.): Munus amicitiae Norbert Oettinger a collegis et amicis dicatum. Ann Arbor / New York: Beech Stave Press. 302-314.

Sasseville, David (2014/2015): Luwian and Lycian agent nouns in *-é-leh ${ }_{2}$. Die Sprache $5^{1.105}-124$.

Schürr, Diether (1997): Lydisches Iv: Zur Grammatik der Inschrift Nr. 22 (Sardes). Die Sprache 39. 201-212.

Schürr, Diether (1999): Lydisches I: Zur Doppelinschrift von Pergamon. Kadmos 38. 163174.

Schürr, Diether (2003): Zur Rekonstruktion altanatolischer Verse. Indogermanische Forschungen 108. 104-126.

Schür, Diether (2006): Elf lydische Etymologien. In: Bombi, Raffaella / Cifoletti, Guido / Fusco, Fabiana / Innocente, Lucia / Orioles, Vincenzo (ed.): Studi linguistici in onore di Roberto Gusmani. Alessandria: Dell' Orso. 1569-1587.

Starke, Frank (1990): Untersuchung zur Stammbildung des keilschrift-luwischen Nomens. Studien zu den Boğazköy-Texten, 31. Wiesbaden: Harrassowitz.

Yakubovich, Ilya (2010): Sociolinguistics of the Luvian Language. Brill's Studies in IndoEuropean Languages and Linguistics, 2. Leiden: Brill.

Yakubovich, Ilya (forthcoming): An agreement between the Sardians and the Mermnads in the Lydian language. Paper presented at the conference "Hot Topics in Anatolian Linguistics (Phonology, Morphology, Syntax) in honor of H. Craig Melchert, Universität Innsbruck, June 3oth 2016.

Yates, Anthony D. (2015): Anatolian default accentuation and its diachronic consequences. Indo-European Linguistics 3, 145-187.

Zeilfelder, Susanne (2001): Archaismus und Ausgliederung. Studien zur sprachlichen Stellung des Hethitischen. Indogermanische Bibliothek: Reihe 3. Heidelberg: Winter. 